\title{
PENINGKATAN KEMAMPUAN PENALARAN MATEMATIKA DENGAN PENDEKATAN SCIENTIFIC TERINTEGRASI PADA MODEL PROBLEM SOLVING
}

\author{
Ika Septi Hidayati, SD Negeri Prembulan, \\ Universitas Cokroaminoto Yogyakarta \\ ikasepti58@gmail.com
}

\section{Abstrak}

Tujuan Penelitian ini adalah mengetahui penerapan pendekatan scientific terintegrasi pada model problem solving yang tepat agar dapat meningkatkan kemampuan penalaran siswa kelas V SD Negeri Prembulan. Hasil penelitian ini menunjukan bahwa: (1) Secara umum penerapan pendekatan scientific terintegrasi pada model problem solving yang tepat, efektif dalam meningkatkan kemampuan penalaran matematika, (2) Peningkatan penalaran matematika siswa kelas V SD Prembulan pada pra siklus sebesar 50,05\% pada siklus I sebesar 76,31\% pada siklus II sebesar $85,39 \%$

Kata Kunci: scientific, problem solving, penalaran

\section{IMPROVING MATHEMATICAL REASONING ABILITY WITH INTEGRATED SCIENTIFIC APPROACH TO THE PROBLEM SOLVING MODEL \\ Ika Septi Hidayati, Prembulan State Elementary School, \\ Cokroaminoto University Yogyakarta \\ Ikasepti58@gmil.com}

\begin{abstract}
The purpose of this study was to determine the application of an integrated scientific approach to the correct problem solving model in order to improve the reasoning abilities of the fifth grade students of SD Negeri Prembulan. The results of this study indicate that: (1) In general, the application of the integrated scientific approach to the correct problem solving model is effective in improving mathematical reasoning skills, (2) Increasing mathematics reasoning of the fifth grade students of SD Prembulan in the pre-cycle by $50.05 \%$ in the cycle I amounted to $76.31 \%$ in the second cycle of $85.39 \%$
\end{abstract}

Keywords: scientific, problem solving, reasoning

\section{A. Pendahuluan}

1. Latar Belakang Masalah

Sumarmo (2003: 35) menyatakan bahwa secara garis besar kemampuan dasar matematika dapat diklasifikasikan dalam lima standar, yaitu 1) mengenal, memahami, dan menerapkan konsep, prosedur, prinsip dan ide matematika 2) menyelesaikan masalah matematika 3) bernalar matematika 4) melakukan koneksi matematika 5) komunikasi matematika. Dalam pembelajaran matematika memiliki salah satu tujuan 
yaitu untuk melatih cara berpikir logis dalam penalaran matematika. Karena antara penalaran dan materi ajar matematika memiliki keterkaitan yang kuat dan tidak dapat diabaikan. Untuk memahami materi ajar matematika dibutuhkan suatu kemampuan penalaran yang baik dan kemampuan penalaran dapat dilatih melalui pembelajaran matematika.

Berdasarkan hasil pengamatan yang dilakukan terhadap siswa Kelas V SD Negeri Prembulan yang berjumlah total 33 siswa, terdiri dari 18 siswa laki-laki dan 15 siswa perempuan diperoleh kemampuan penalaran matematika yang dimiliki siswa masih kurang maksimal. Terbukti dari hasil observasi awal Rendahnya kemampuan penalaran matematika siswa disebabkan oleh Hal itu disebabkan oleh kurang variasinya guru dalam menyampaikan materi di kelas dan perhatian siswa didalam kelas saat pembelajaran matematika masih kurang. Sehingga pembelajaran matematika kurang maksimal, mengakibatkan kemampuan penalaran matematika siswa rendah. Selain itu siswa cenderung tidak menuliskan apa yang diketahui dari soal sehingga mengisyaratkan bahwa siswa kurang mampu menangkap ide pokok permasalahan yang kemudian ditampilkan dalam bahasa matematika. Sehingga saat seorang siswa dihadapkan sebuah permasalahan matematika sebagian besar kurang maksimal dalam menyelesaikan permasalahan matematika tersebut.

Berdasarkan akar penyebab masalah pemilihan pendekatan pembelajaran dan model pembelajaran yang tepat diharapkan mampu memberikan kesempatan dan sarana bagi siswa untuk meningkatkan kemampuan penalaran mereka. Salah satu alternative tindakan yang dapat digunakan untuk mengatasi permasalahan tersebut adalah dengan menggunakan pendekatan Scientific terintegrasi pada model problem solving. Penggunaan pendekatan Scientific dalam pembelajaran matematika dapat menjadi salah satu sarana untuk menumbuh-kembangkan kemampuan penalaran matematika siswa. Nurul (2013) menyebutkan bahwa pembelajaran dengan pendekatan Scientific merupakan pembelajaran yang menggunakan pendekatan ilmiah dan inkuiri, dimana siswa berperan langsung baik secara individu maupun kelompok untuk menggali konsep dan prinsip selama kegiatan pembelajaran, sedangkan tugas seorang guru adalah mengarahkan proses belajar yang dilakukan siswa dan memberikan koreksi terhadap konsep dan prinsip yang diperoleh siswa. Sedangkan metode pembelajaran problem solving menurut Mulyono (2012: 108) merupakan suatu metode berpikir, sebab dalam metode problem solving dimulai dengan mencari data 
sampai dengan menarik kesimpulan. Adapun tahapan dalam problem solving yang diajukan oleh Polya antara lain,
a. memahami permasalahan matematika
b. merencanakan penyelesaian permasalahan
c. melaksanakan rencana penyelesaian, dan
d. melihat kembali hasil yang telah diperoleh.

2. Teori yang digunakan

Penggunaan pendekatan Scientific dalam pembelajaran matematika dapat menjadi salah satu sarana untuk menumbuh-kembangkan kemampuan penalaran matematika siswa. Nurul (2013) menyebutkan bahwa pembelajaran dengan pendekatan Scientific merupakan pembelajaran yang menggunakan pendekatan ilmiah dan inkuiri, dimana siswa berperan langsung baik secara individu maupun kelompok untuk menggali konsep dan prinsip selama kegiatan pembelajaran, sedangkan tugas seorang guru adalah mengarahkan proses belajar yang dilakukan siswa dan memberikan koreksi terhadap konsep dan prinsip yang diperoleh siswa. Sedangkan metode pembelajaran problem solving menurut Mulyono (2012: 108) merupakan suatu metode berpikir, sebab dalam metode problem solving dimulai dengan mencari data sampai dengan menarik kesimpulan. Adapun tahapan dalam problem solving yang diajukan oleh Polya antara lain, 1) memahami permasalahan matematika 2) merencanakan penyelesaian permasalahan 3) melaksanakan rencana penyelesaian, dan 4) melihat kembali hasil yang telah diperoleh.

Sesuai dengan uraian diatas, pendekatan Scientific terintegrasi pada model problem solving adalah pendekatan Scientific yang penerapannya masuk ke dalam model problem solving. Model pembelajaran yang merangsang kemampuan penalaran matematika siswa dirancang dengan pendekatan Scientific yang terintegrasi pada model problem solving. Tujuan untuk meningkatkan kemampuan penalaran matematika siswa diyakini akan berhasil dalam pembelajaran secara kolaboratif dengan membuat sekelompok siswa untuk menyelesaikan permasalahan matematika. Dengan pembuatan kelompok secara heterogen, yaitu dengan membentuk kelompok yang didalamnya terdapat siswa yang memiliki tingkat kecerdasan yang berbeda. Kemudian sekelompok siswa diberikan suatu permasalahan matematika yang kemudian didalam sebuah kelompok tadi membahas cara penyelesaian permasalahan yang dihadapi oleh kelompok tersebut. Di tahap akhir pembelajaran sekelompok siswa dikondisikan untuk dapat mengkomunikasikan hasil yang telah didapat dalam kelompok terkait alur penyelesaian permasalahan yang dihadapi. Setelah itu, kelompok lain dapat memberikan 
pertanyaan atau tanggapan terkait hasil yang telah dipaparkan kelompok yang pertama. Kemudian guru memberikan klarifikasi hasil dan pertanyaan atau tanggapan dari kelompok.

Adapun Langkah-langkah pendekatan Scientific terintegrasi pada model pembelajaran problem solving : 1) memahami permasalahan, dengan mengamati sumber belajar yang telah tersedia, guru mengkondisikan siswa dengan sebaik-baiknya agar dapat mengikuti pembelajaran dengan baik. Kemudian guru menerangkan materi pembelajaran dengan menggunakan sumber belajar, setelah itu guru memberikan suatu permasalahan matematika yang dapat diaplikasikan dalam kehidupan sehari-hari. Setelah diberi suatu permasalahan oleh guru, siswa diharapkan dapat mencermati dan memahami permasalahan yang telah diberikan. Siswa diharapkan dapat bertanya kepada siswa lain ataupun guru mengenai permasalahan. Apabila belum ada pertanyaan yang muncul, guru dapat merangsang siswa sehingga siswa dapat bertanya menandakan bahwa siswa telah memahami permasalahan yang diberikan, 2) merencanakan penyelesaian, pertanyaan yang diajukan oleh salah satu siswa dapat memberikan rangsangan untuk merencanakan alur penyelesaian yang tepat dari permasalahan yang diberikan. Kemudian sekelompok siswa menggali informasi untuk dapat menyelesaikan permasalahan. Siswa dapat merencanakan penyelesaian permasalahan dengan menggunakan beberapa alur penyelesaian, 3) melaksanakan perencanaan penyelesaian, beberapa perencanaan alur penyelesaian permasalahan yang telah diperoleh, pada tahap ini siswa mencoba dan melaksanakan perencanaan penyelesaian permasalahan dengan memilih salah satu dari beberapa alur penyelesaian. Kemudian siswa mencoba menyelesaikan permasalahan, sehingga akan diperoleh hasil akhir penyelesaian permasalahan yang dapat dibentuk dalam sebuah ringkasan berupa tabel dan grafik, 4) melihat kembali, pada tahap akhir siswa dianjurkan dapat melihat kembali hasil yang telah diperoleh. Kemudian siswa menyajikan hasil yang telah diperoleh dalam bentuk laporan tertulis kemudian sekelompok siswa dapat mengkomunikasikan laporan secara tertulis di depan kelas. Kelompok lain dapat memberikan tanggapan dan pertanyaan terkait hasil yang telah diperoleh. Kemudian guru mengklarifikasi hasil yang telah diperoleh dan guru memberikan penghargaan kepada siswa atas kerja keras yang telah ditunjukkan dalam pembelajaran. Pada akhir pembelajaran, guru bersama siswa dapat menarik kesimpulan mengenai materi yang telah dipelajari.

\section{Metode Penelitian}

Jenis penelitian ini merupakan Penelitian Tindakan Kelas (PTK) atau Classroom Action Research (CAR) yang dilakukan melalui proses kerja kolaborasi antara guru matematika dan peneliti sehingga tujuan dari penelitian ini, yaitu pembelajaran di kelas lebih efektif dapat terlaksana. Tjipto Subadi (2010: 30) menyebutkan bahwa PTK adalah suatu penelitian yang dilakukan berdasarkan adanya permasalahan nyata yang 
muncul di kelas. Kegiatan penelitian ini berangkat dari permasalahan nyata yang sedang dihadapi oleh guru dalam proses belajar mengajar. Kemudian permasalahan tersebut dipecahkan dengan melalui tindakan nyata. Penelitian tindakan kelas merupakan kegiatan pemecahan masalah yang dimulai dari perencanaan, pelaksanaan, pengawasan, refleksi dan evaluasi.

Penelitian ini dilaksanakan di SD Negeri Prembulan. Subjek penelitian ini adalah guru dan siswa kelas V. Subjek penerima tindakan adalah siswa kelas V yang berjumlah 33 orang, terdiri dari 18 siswa laki-laki dan 15 siswa perempuan dan subjek pelaku tindakan yaitu guru matematika kelas VIII D. Selain bertindak sebagai observer, peneliti juga bertugas mendiagnosis, membuat konsep dan merancang tindakan bersama guru matematika. Data dalam penelitian ini dikumpulkan melalui metode observasi, catatan lapangan, wawancara, dokumetasi dan tes. Observasi digunakan untuk merencanakan tindakan selanjutnya, wawancara digunakan sebagai komunikasi awal untuk memperoleh informasi yang diperlukan, dokumentasi untuk mendukung dan menambah kepercayaan dan pembuktian suatu masalah, dan tes untuk mengukur kemampuan objek yang diteliti. Data penelitian yang dikumpulkan berupa informasi mengenai kemampuan penalaran matematika pada siswa dan kemampuan guru dalam menyusun rencana pembelajaran serta melaksanakan pembelajaran dengan menggunakan pendekatan Scientific terintegrasi pada model problem solving di kelas. Data penelitian dikumpulkan dari berbagai sumber meliputi: 1) Informan atau narasumber, yaitu guru dan siswa, 2) Tempat dan peristiwa berlangsungnya aktivitas pembelajaran matematika dan aktivitas lain yang berkaitan; dan 3) Dokumen atau arsip, yang antara lain berupa kurikulum, rencana pelaksanaan pembelajaran, dan buku penilaian (Sutama, 2010:166).

Dalam Lexy J. Moleong (2011: 178) ada empat macam triangulasi sebagai pemeriksaan yang memanfaatkan penggunaan sumber, metode, penyelidik dan teori. Peneliti menggunakan triangulasi sumber, yaitu pengecekan data pengamatan hasil tes, observasi dan dokumentasi; serta dipadukan dengan dan triangulasi metode, yaitu dengan membandingkan data dan dengan memanfaatkan penggunaan beberapa metode pengumpulan data seperti observasi, wawancara, catatan lapangan, dan hasil dokumentasi. Analisis data dalam penelitian ini dilakukan melalui 3 langkah pokok, yaitu: 1) pengumpulan data, 2) penyajian data, dan 3) verifikasi data. 


\section{B. Hasil Penelitian dan Pembahasan}

Untuk mengetahui sejauh mana peningkatan penalaran pada setiap siklusnya. Dari hasil pengamatan dari pra siklus, siklus I, siklus II peningkatan penalaran siswa dalam pembelajaran matematika meningkat. Pendekatan Scientific terintegrasi pada model pembelajaran problem solving dapat meningkatkan kemampuan penalaran matematika, dengan langkah-langkah: 1) memahami permasalahan, dengan mengamati sumber belajar yang telah tersedia, guru mengkondisikan siswa dengan sebaik-baiknya agar dapat mengikuti pembelajaran dengan baik. Kemudian guru menerangkan materi pembelajaran dengan menggunakan sumber belajar, setelah itu guru memberikan suatu permasalahan matematika yang dapat diaplikasikan dalam kehidupan sehari-hari. Setelah diberi suatu permasalahan oleh guru, siswa diharapkan dapat mencermati dan memahami permasalahan yang telah diberikan. Siswa diharapkan dapat bertanya kepada siswa lain ataupun guru mengenai permasalahan. Apabila belum ada pertanyaan yang muncul, guru dapat merangsang siswa sehingga siswa dapat bertanya menandakan bahwa siswa telah memahami permasalahan yang diberikan, 2) merencanakan penyelesaian, pertanyaan yang diajukan oleh salah satu siswa dapat memberikan rangsangan untuk merencanakan alur penyelesaian yang tepat dari permasalahan yang diberikan. Kemudian sekelompok siswa menggali informasi untuk dapat menyelesaikan permasalahan. Siswa dapat merencanakan penyelesaian permasalahan dengan menggunakan beberapa alur penyelesaian, 3) melaksanakan perencanaan penyelesaian, beberapa perencanaan alur penyelesaian permasalahan yang telah diperoleh, pada tahap ini siswa mencoba dan melaksanakan perencanaan penyelesaian permasalahan dengan memilih salah satu dari beberapa alur penyelesaian. Kemudian siswa mencoba menyelesaikan permasalahan, sehingga akan diperoleh hasil akhir penyelesaian permasalahan yang dapat dibentuk dalam sebuah ringkasan berupa tabel dan grafik, 4) melihat kembali, pada tahap akhir siswa dianjurkan dapat melihat kembali hasil yang telah diperoleh. Kemudian siswa menyajikan hasil yang telah diperoleh dalam bentuk laporan tertulis kemudian sekelompok siswa dapat mengkomunikasikan laporan secara tertulis di depan kelas. Kelompok lain dapat memberikan tanggapan dan pertanyaan terkait hasil yang telah diperoleh. Kemudian guru mengklarifikasi hasil yang telah diperoleh dan guru memberikan penghargaan kepada siswa atas kerja keras yang telah ditunjukkan dalam pembelajaran. Pada akhir pembelajaran, guru bersama siswa dapat menarik kesimpulan mengenai materi yang telah dipelajari.

Adanya peningkatan kemampuan penalaran matematika dengan menggunakan pendekatan Scientific terintegrasi pada model pembelajaran problem solving dapat dilihat pada indikator-indikator sebagai berikut:

a. Kemampuan mengajukan dugaan awal siswa sebelum tindakan sebanyak sebanyak 15 siswa, pada siklus I menjadi sebanyak 23 siswa dan siklus II sebanyak 30 siswa. 
b. Kemampuan menemukan pola penyelesaian permasalahan sebelum tindakan sebanyak 9 siswa pada siklus I menjadi sebanyak 16 siswa dan pada siklus II menjadi sebanyak 25 siswa.

c. Kemampuan manipulasi matematika siswa sebelum tindakan sebanyak 9 siswa setelah siklus I menjadi sebanyak 15 siswa dan setelah siklus II menjadi sebanyak 21 siswa

d. Kemampuan menarik kesimpulan siswa sebelum tindakan sebanyak 6 siswa, pada siklus I menjadi sebanyak 14 siswa dan pada siklus II meningkat menjadi 22 siswa.

\section{Daftar Pustaka}

Abdullah, A. G., \& Ridwan, T. (2008). Implementasi Prblem Based Learning (PBL) pada Proses Pembelajaran di BPTP Bandung. Prosiding UPI, pp. 1-10.

Atsnan, M.F., \& Gazali, R.Y. (2014). Peneraapan Pendekatan Scientific dalam Pembelajaran Matematika SMP Kelas VII Materi Bilangan (Pecahan). Prosiding, ISBN: 978-979-16353-9-4.

Bakri, H. (2009). Peningkatan Minat Belajar Praktek Menggulung Trafo Melalui Pendekatan Pembelajaran Berbasis Masalah (Problem Based Learning) Pada Siswa SMK Negeri 3 Makassar. Jurnal MEDTEK, $1,1$.

Brown, J. R., \& Dant, R. P. (2008). Scientific Method and Retailing Research: A Retrospective. Journal of Retailing, 84, 1-13.

Mulyono. (2012). Strategi Pembelajaran. Malang : UIN-Maliki Press

Leksono, J. W. (2014). Pendekatan Saintifik pada kurikulum 2013 untuk meningkatkan kemampuan berpikir kritis siswa. Prosiding Konvensi Nasional Asosiasi Pendidikan Teknologi dan Kejuruan.

Muharom, T. (2014). Pengaruh Pembelajaran Dengan Modl Kooperatif Tipe STAD Terhadap Kemampuan Penalaran dan Komunikasi Matematik Peserta Didik. Jurnal Pendidikan dan Keguruan, 1, 1.

Nurdalilah. (2012). Perbedaan Kemampuan Penalaran Matematika dan Pemecahan Masalah Pada Pembelajaran Berbasis Masalah dan Pembelajaran Konvensional. Jurnal Pendidikan Matematika PARADIKMA, 2, 109-109.

Nurul, H. (2013). Pengertian dan Langkah - Langkah Saintifik. Diakses pada tanggal 3 Oktober 2015 pkl 10.56 WIB, dari http://www.nurulhidayah.net/879pengertian-dan-langkah-pembelajaran-saintifik.html.

Subadi, T. (2010). Lesson Studi Berbasis PTK (Penelitian Tindakan Kelas): Suatu Model Pembinaan menuju Guru Profesional. Surakarta: Badan Penerbit FKIP UMS 
Sudjana, N. (2006). Dasar-Dasar Proses Belajar Mengajar. Bandung: Sinar Baru.

Suherman dkk, E. (2003). Strategi Pembelajaran Kontemporer. Bandung : UPI.

Sumarmo, U. 2003. Pembelajaran Keterampilan Membaca Matematika pada Siswa Sekolah Menengah. Makalah pada Seminar Nasional Nasional Pendidikan Sains dan Matematika. [23 Agustus 2003] kerjasama JICA dan FPMIPA UPI, Bandung.

Yuniarti, T., Riyadi, Subanti, S. (2014). Pengembangan Perangkat Pembelajaran Berbasis Masalah dengan Pendekatan Ilmiah Pada Materi Segitiga Kelas VII SMP Se-Kabupaten Karanganyar Tahun Pelajaran 2013/2014. Jurnal Elektrnik Pembelajaran Matematika. 2, 9, 911-921. ISSN: 2339-1685 